\title{
Architectural Drawings do not Represent
}

\author{
Mike Linzey
}

\section{Introduction}

Most people view architectural drawings as a means to an end, a mode of communication, a medium of expression. Even most architects usually describe their own drawings as representations of something else, as pointing towards some future condition of architecture that matters more than mere drawings, or as imperfect representations of some prior and usually superior theoretical ideal. Drawings for most architects are only a sign, a semiotic device that points away from itself towards what truly matters. Most people don't think very much about drawings at all, but when they do it is often in this middling, muddling, drawing-doesn't-matter sort of way.

People who do think usually identify two other kinds of being as well. Effectively they recast the task of drawing in the form of a representational project. Juliana Pallasmaa, for example, says that the energetic lines and smudges on the page of a drawing represent a kind of muscular memory in the bodily experience of the draftsperson (Pallasmaa 2009: 89-105), and Mark Wigley says that the "almost-nothing" gossamer condition of architectural drawings stands for or withers in contrast to the excessive materiality and the blinding super-sufficiency of architecture itself (Wigley 2008). Karl Popper declared that drawings are "objective ideas" (Popper 1972, 1994). He made the radical claim that human constructs such as architectural drawings, orchestral scores, mathematical theorems and scientific theories are ideas in their own right. Yet Popper also took perhaps the most exaggeratedly representational position when he said that these drawn ideas occupy a kind of "world" of objective forms and signifiers, and that their primary function is to negotiate "interactions" between two other "worlds" of experiential thought and physicality, between mind and matter. Thus his very important empirical insight rapidly descended into yet another modern version of Platonism. Martin Heidegger's unitary "world" on the other hand has the same sense of being-in-ness and historical timeliness as Popper's three worlds, but without reducing epistemology to a kind of semiological conjecture.

Most people who think about drawing do not write about it. Even people who do write about it often persist in calling architectural drawings a mode of reference to something else. Representation is such an easy language to slip into. Pallasmaa does it. Wigley does it, as we shall see shortly. We spent years at my own school trying to keep the words "representation" and "communication" out of our descriptions of the architectural drawing curriculum. We did not succeed. 
My simple-minded proposition then is this: that architectural drawing is not essentially a mode of representation and communication. Drawings are instead autonomous and novel architectural ideas. It is not their primary function to represent something else, but to present themselves as something new. On one hand they do not represent the private experiences of the architect who draws them, since architects do not have clear and distinct architectural ideas other than those we discover in a drawing. Nor do drawings re-present what Vitruvius called the operis futuri figura, the future form of an intended built work. The issue here is one of strict temporal ordering. It is drawings that take priority in time, and building follows.

This is not to deny that drawings often do mediate between architects and architecture or between architecture and buildings in the ways that Popper calls interactions (1994). For example, many aspects and details of Iktinos's drawings for the classical Parthenon would have also represented the forms and ratios of earlier temples in the Doric style. What I am saying is that representation is not their primary role and function. Drawings work more "truthfully" in another way altogether, as autonomous performances of innovative meaning. In his fine essay on the almost-nothing of architectural drawings, Mark Wigley says at one stage that drawings are neither an idea nor an object (Wigley 2008: 157). But I want to say the opposite to this, that drawings are both a graphical object and a performative idea, literally as Vitruvius stated it. Drawings are the graphical diathesis through and within which an architect sets out and discovers an idea for the first time. I want to explore in this paper other ways of describing architectural drawings, additional to representation and communication and interaction, that we can share and understand in this diathetical sense.

In Heidegger's terms, I will argue that drawings are the being of architecture. Drawings are a kind of this-worldly and historical entity that dispel the darkness and reveal the meaning of architecture as energy and performance and light. Heidegger said "the world worlds" (1971: 44). I would say that drawings draw architecture out of the night of academic mystification and representational thought, into a creative world of an altogether more relevant and timely kind of architectural discourse. Heidegger did not discuss architectural drawings as such, but I argue, if it were not for drawings there would be no effective language of building, dwelling and thinking. Drawing is the originary "language" of architecture; it is a graphical language but this does not mean that it represents thinking or building or ideas about dwelling any more than it represents the heavy substance of a stone wall that is yet to be built or than it represents the experience of a muscular prehension that is never otherwise articulated and expressed so clearly. Like a gift to architecture, a drawing presents the dramatic truth of being-in-the-world and being-in-time. It brings architecture to light inthe-world, in-time, and for the first time.

\section{Drawing the Parthenon}

In order to set the scene for a discussion of the phenomenology of architectural drawings, my essay begins by recounting a story that will already be familiar to many architectural readers. John Coulton (1977: 112-3) describes how the original drawings of the Parthenon would have brought the classical vision of the Greek gods into an enhanced light compared to other temples that had been built and 


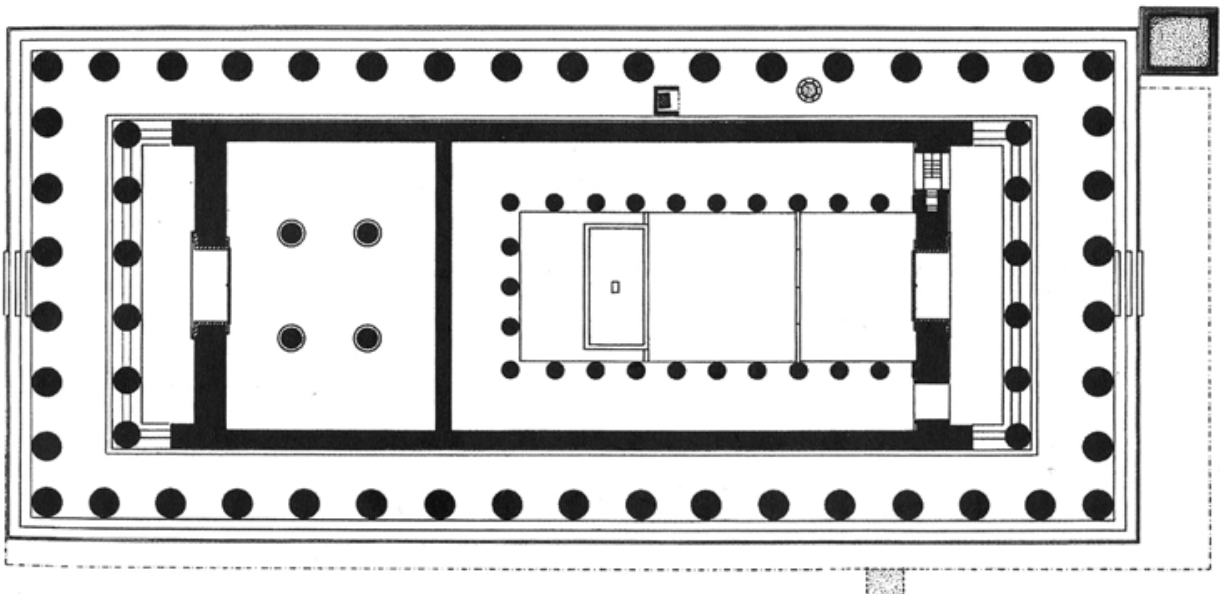

1.T.

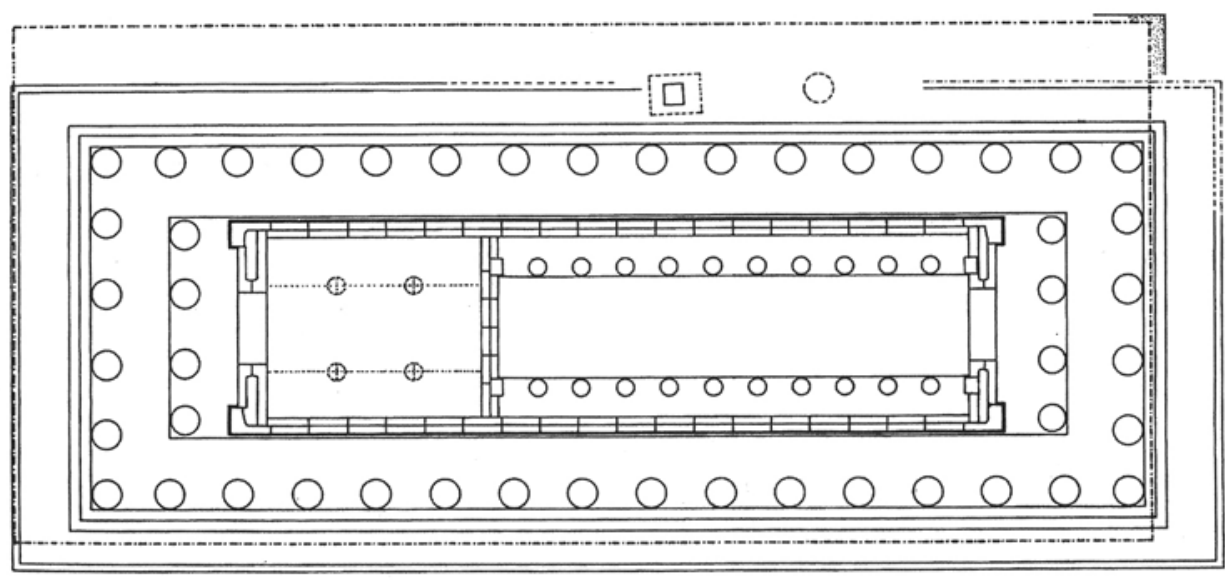

planned in the Doric tradition. I invite us to imagine an aesthetic debate raging around the presentation of this new idea for the Parthenon, and how this debate over drawings may have been misconstrued as irrational by Socrates.

Let us imagine then this key moment in the history of architectural ideas. It was the year 450 BC. Socrates would have been 19 years old when Iktinos the architect presented his drawings for the Parthenon for the very first time. We may imagine a bundle of wax tablets, scratchings on stone or paintings on wood or leather sheets, and let us say that the primary audience at this presentation was the sculptor/architect Pheidias. Coulton (1977) calls this one of the most original and interesting presentations of an idea in the whole history of Greek architecture. Borrowing from Heidegger we would say that Iktinos's drawings were the coming-into-presence of the meaning of the Parthenon within-time and for the first time, at least so far as Pheidias and Socrates were concerned. These wax impressions et cetera were the first historical intimation of what would shortly become the most beautiful temple in the world of Athenian architecture.

"Look how beautiful is the Parthenon!" said Iktinos the architect. (Laertius 1925: 177 [VII 67]) The Greek word he would have used was kalos, from which, in Heidegger's sometimes erratic tradition, we may be licensed to misconstrue that the word calorific also derives. "Look at this hot new architecture!" Iktinos showed Pheidias the now-famous front elevation of the Parthenon, a sea of columns proudly drawn in the Doric style. Coulton leads us to imagine next that Pheidias responded negatively to this idea. The negative of kalos is aishros, meaning ugly and shameful.
Fig. 1 Plans of the classical Parthenon and the older Parthenon drawn to the same scale. Courtesy M. Korres. 
Fig. 2 An indicative construction for a scenographia drawing, photo-montaged by the author from various sources.

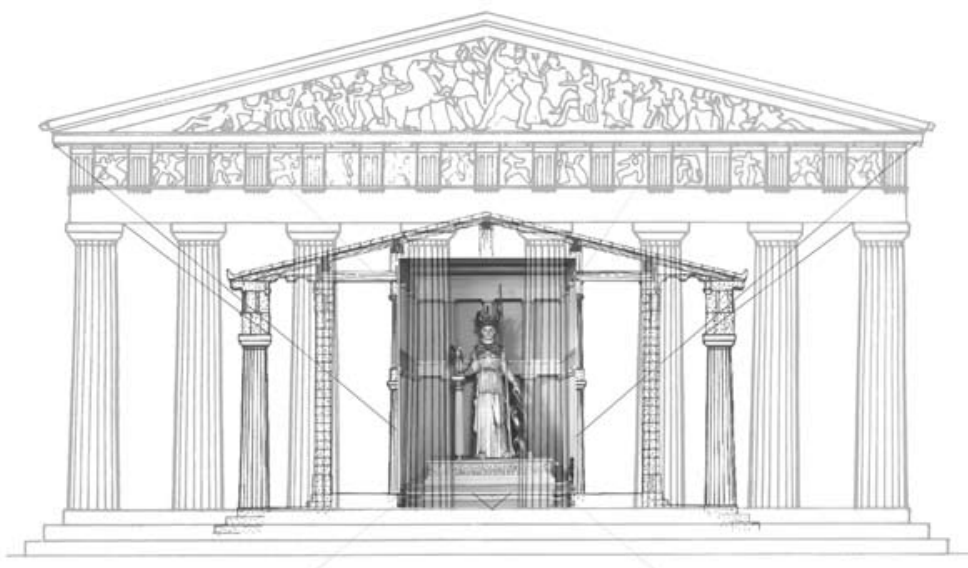

"It is a shameful attempt," Pheidias might have said, "There are too many columns." The canonical Doric temple only had six columns on its front elevation. In the temple of Zeus at Olympia, for example, into which Pheidias would later install his most famous sculptural work, the architect Libon had provided the correct number, six columns. But Iktinos presented here an orthographic composition with eight columns.

"What are you trying to produce here," Pheidias might have asked, "a pseudodipteron in the degenerate style of the Ionians?" To Pheidias's eyes what Iktinos had drawn was not hot, it was pseudés, false, striving for effect. The situation we are imagining here was like an architectural design critique. Pericles and the citizens of Athens had placed Pheidias in overall charge of all the new work on the Acropolis. Pheidias did not want the new god-house for Athena to be ugly, shameful and false, and he challenged the drawing on aesthetic grounds.

Iktinos replied with a comparative drawing, and we imagine now a pair of plans as in Fig. 1, laid out in order to explain his rationale.

By introducing two additional columns, he said, and with the outer faces of the cella walls aligned as is proper with the centre-lines of the columns one in from each corner, then more width is provided in the interior of the cella. According to Coulton's measurements the free space between the inner colonnades in the eastern cella of the classical Parthenon is 9.82 metres, where the equivalent measurement at Olympia is only 6.35 metres. In the older Parthenon that previously had been destroyed by the Persians, and that Iktinos and Pheidias were effectively rebuilding from scratch, the equivalent width is estimated to have been about 6.8 metres. So Iktinos's drawing provided Pheidias an extra three metres of space in which to display the new chryselephantine cult figure.

A few octastyle Doric temples had previously been built in Italy and Greece, but none that we know of had yet employed this novel strategy to widen the interior space of the cella at the expense of the exterior perambulatory spaces. In the most theatrical kind of drawing that Vitruvius called scenographia, Iktinos may have shown how beautifully the Parthenon uses this extra width to display the goddess to the best effect. "Look," Iktinos would have said, "how previously the goddess was enframed in a narrow dark corridor of space. In the conventions of the Doric style, at Olympia, Libon has given your masterwork a dark and hidden look. But here at Athens the goddess is revealed standing comfortably in her disclosedness (alétheia) with two high windows let into the eastern wall of the 
cella to introduce the first light of dawn into the interior colonnaded spaces and with room even for the internal columns to return and bounce the light around behind her. In this way too Athena is presented in an interior room that has the same base proportions (4:9) as also applies to the exterior proportions of the temple. Is this not truly a more beautiful setting than the narrow corridor of space that the Doric ideal would otherwise provide?"

\section{The academic view on representation}

Let us continue this historical reverie in order to speculate about the willfulness of academic theory. Let us imagine that the 19-year-old Socrates audited this heated exchange, heard these strong and emotionally loaded words, kalos, meaning beauty, alétheia, meaning truth, pseudés, meaning false, eidos and its cognate idea, meaning an architectural image impressed into wax, fought over with passion and energy by these god-like beings. Socrates may have tried to record or critique or undermine the dialectical vitality of these god-like beings, Pheidias and Iktinos. Perhaps he willfully distorted what he had seen for reasons known only to himself, or perhaps he simply got it wrong.

Something, anyway, inspired Socrates to found a school of thought in which craftsmen were cast as lesser beings, and artists as altogether removed from access to alétheia. The academic philosophers who came after Socrates conspired through various analogies and expressive devices to strip the language of its dialectical vitality and reduce it to the representational conventions that we know today. The academic viewpoint so dominates our thinking that we are almost compelled to accept as true that the Parthenon represents Plato's timeless and perfect ideal form of architecture. Every word represents a perfect idea, so any particular assemblage of stones to which we apply the name "temple" is only a rough and inferior copy of the idea, "temple". We assume any drawings that Iktinos may or may not have produced would merely have mediated and communicat$e d$ these wonderful ideas between the architect's mental experiences of an exact theoretical vision or intuition and the inexact world of practical temple-building. This is despite the glaring historical anomaly that this view implies.

One of the more potent ideas that are contained in the academic discourse has been Plato's analogy of the divided line. In Book 6 of The Republic (509d-513e) Plato effectively suggested that human apprehension can be divided into a bodily part and an intellectual part. And just as with the body, touching something with the hand usually provides more obscure impressions than things that are seen with the eyes, so also on the intellectual side, our apprehension of mathematical ratios are supposedly less clear and our intuitions of "pure ideas" in the timeless realm of forms are supposedly the most clear and direct of all. Our views about ideas continue to be shaped by this analogy even though we also know that it is antiquated and unscientific. Already in antiquity Aristotle was more than a little uneasy about the academic theory of ideas, and Zeno and the Stoics clearly knew what Herophilus and Eristratus had discovered early in the third century BC, that human psychology conforms to the musculature of the body; the eyes not only see things through the massive optic nerves but they also look for the forms of things, interrogate the world and images of the world through patterned searches that are known as rapid eye movements and are governed by the smaller oculomotor nerves; and our hands not only touch things and feel hot and cold but they also grasp things in the distinctively human pre- 
hensile fashion. Everywhere throughout the body, the Greeks knew that our nervous system runs in pairs. Grasping a pencil or a digital device and drawing with it is an intellectual skill that is governed not only by the complex system of mechano-receptor neurons of the hand, but all of the neural pathways are engaged in drawing - feeling the texture of the paper with the hand, seeing it with the eye, searching for form and meaning also with the eye but in an energetic and muscular mode of looking, as well as drawing and smudging the page with the energetic musculature of the arm and hand.

\section{A phenomenology of drawing in three stages}

In Being and Time (1927) Heidegger set out through phenomenology to recover the pre-Socratic and non-academic meaning of being. Although the purview of his argument did not extend to architectural drawings, yet I argue there is much of value to be drawn from studying his text. What is thoroughly non-representational about Heidegger's phenomenology is effectively summed up by the German word, Dasein. The profoundly unitary and this-worldly quality of this word is usually marked with hyphens in English translations. Dasein means being-inthe-world. Heidegger's version of being is down-to-earth whereas the academic versions of it were always at least quasi-divine. Being-in-the-world signifies for Heidegger the primordial and energetic unity of all aesthetic productions of a technically proficient Dasein, and architectural drawings of course are one kind of aesthetic production.

Rather than locating ideas as the academics did in a nebulous and timeless world at the far end of Plato's divided line, Heidegger reappointed all meaning into this-world-here, being-here, being-in-time. We may think of Heidegger's Dasein as something like a Greek craftsperson: what Hippocrates called a technités. Dasein is someone who would rather take care of their own equipment, ensure their tools were sharp and true, even in the face of their own death. Heidegger employed this technical device in opposition to the anti-technical world-view of the likes of Socrates, Plato and, to some extent, Aristotle. Phenomenology then is a non-academic approach to art and work. While with Socrates and Plato the essential ideas were other-worldly, divorced from art and craft, and a-historical, Heidegger opposes to this what he calls Dasein's intrinsic temporality and historicality and its work-man-like nature. His analysis is grounded in concepts of readiness-to-hand and presence-at-hand, concepts that refer to and build upon the prehensile musculature and the limited sensitivity of the hands of a manually adept technités.

As such, however, there is nothing about the visible aspect of drawings in Heidegger's basic notions of Dasein. A phenomenology of drawing requires that the eye also be engaged along with these hand-related phenomena. The question of visuality does come into play in Being and Time, but only relatively late in the book, after page 376 of the McQuarrie/Robinson translation, where Heidegger introduces what he calls the "moment of vision" (Augenblick) in relation to an analysis of the ontological meaning of care. Our outline phenomenology of architectural drawings then proceeds in three stages: from readiness-to-hand to presence-at-hand to the moment of vision. In other words it will proceed from prehension to apprehension to comprehension.

These three terms, prehension, apprehension and comprehension, all relate to grasping. The word "comprehension" that we usually associate with mental ac- 
tivity, therefore entirely and academically separate from the body, actually derives from Cicero's translation of the Stoic technical term, katalépsis. Katalépsis means to grasp something firmly and resolutely, as if with the hand. Comprehension for Dasein is not a disembodied mental act. It is more correct to signify it as closing a loop in the neural network between the eye and the hand of a technically proficient Dasein.

\section{Stage I. readiness-to-hand}

In readiness-to-hand (Zuhandenheit), a piece of equipment is grasped thematically and energetically put to use in an appropriate technical context. An architect grasps a pen in the already knowing and skilful role of being an architect. There is to be no hint of "learning how to draw" in the phenomenology of drawing. Heidegger only emphasises (1962: 98) how differently it is that one seizes upon a piece of manual equipment, grasps it and puts it to use, compared to staring at it disdainfully or refusing to work at all, on theoretical grounds. The sense of temporality, that is prehended readily-to-hand using the muscles and mechanoreceptor cells of the hand, Heidegger likens to the rhythmic beat-beat-beat of a hammer at work, or the stitching rhythm of a tailor's needle and so on. Manual work takes time. It cannot be done without a proper sense of timing. Yet with this kind of temporality often there is no great sense of the passing of time nor is one often aware of the historical significance of what one might be working at. It is not to say that the prehensile technités is blind, for the rhythmic manipulation of work must be guided proficiently and closely by the eye, but Heidegger calls this kind of workman-like sight "circumspective" vision, which is to say that one tends to look around the equipment and around the workshop or studio, not so much looking at it. In a strange way, what grasps and what is grasped circumspectively are not differentiated within readiness-to-hand. Technical equipment seems to dissolve into the prehensile body. The medium of drawing dissolves into the act of drawing. There is neither space nor time nor vision for ideas to make an appearance in the prehensive mode of readiness-to-hand.

\section{Stage 2. presence-at-hand}

In the second stage, which Heidegger calls presence-at-hand (Vorhandenheit), the regular rhythm of work-time is held up and suspended. This may be for a variety of reasons. Entities that are most closely to-hand may be encountered as something unusable. The hammer may be too heavy, the needle or the plane blade too blunt. Or maybe something is missing, equipment that should be tohand is not to-hand. Or maybe something else related to the work just cannot be made to budge. We can imagine Iktinos working away at his drawings. Say his charcoal pencil breaks or a scribing tool is blunt; this would be only a minor interruption, and presence-at-hand might scarcely announce itself at all in such circumstances. But say he encounters the intractable problem of determining a suitable scale and proportion in the hexastyle form to accommodate Pheidias's giant sculpture: with a problem like this, Heidegger's analysis suggests, Iktinos would have obtained a "pre-phenomenal glimpse" of architectural worldhood that was unique and thoroughly original. No longer simply prehended, and no longer viewed circumspectively, instead all of his defective attempts at drawing would have been scrutinised and stared at in an extreme of apprehension. For that which cannot be budged calls attention to itself in presence-at-hand in the 
mode of conspicuousness, obtuseness and obstinacy. And, in such extreme circumstances, Heidegger says, the whole workshop and the context of equipment would become lit up in a mode of vision that is totally different than circumspection. We imagine the musculature around Iktinos's eyes working overtime, searching everywhere for a new kind of form. What is lit up in presence-at-hand is "disclosed" and "laid open"; it takes on the character of alétheia. (Heidegger 1962: 102-5)

\section{Stage 3. The moment of vision}

But to stare at something apprehensively is not yet to understand it. Comprehension comes in a third stage of phenomenology that Heidegger calls the moment of vision (Augenblick). "The moment of vision," Heidegger writes, "permits us to encounter for the first time what can be 'in a time' as ready-to-hand or present-at-hand" (Heidegger 1962: 388, Heidegger's emphasis).

At this stage in the phenomenology of drawing, the eye is fully engaged along with the hand. Augenblick literally means at "a glance", but Heidegger makes it clear that vision is understood here in an active sense, not just seeing a vision passively passing before our eyes like idly watching a cinematic presentation with merely a glance of the eye, but an active alert participatory kind of lookingat-that-which-stands-out. In our case Iktinos "glances" at his latest drawings in a state of resolute rapture. He sees and comprehends the octastyle idea. He is acutely aware of its timeliness, beauty and historical significance. This critical and originary kind of phenomenological vision, I argue, is never achieved when drawings are treated merely as medial tokens of reference to transcendental ideas that are outside of the ecstatic present and presentation of the drawing itself. This is why it is important to draw attention to this other aspect of a drawing's function that is ideational but non-representational.

Heidegger does not go on to describe a possible fourth stage in the technical phenomenology in which work reverts and resumes its primordial rhythm. The statement, "[T]hen - when it dawns - it is time for one's daily work," (Heidegger 1962: 467) does not, I think, capture that most peculiar phenomenon of all, where what had formerly been stared at and disclosed as a problem in presence-athand, and then discovered in the eureka-like ecstasy of the historical moment of vision, now mysteriously rapidly and quietly subsides into the former kind of circumspective invisibility of readiness-to-hand.

To rehandle a hammer or to lighten an interior room requires no great feat of the imagination after it has been done the first time. After Iktinos completed his work at Athens he went on to Bassae where he designed the famous temple of Apollo Epikorios, facing North and reverting to the traditional hexastyle Doric format. The new work at Bassae was not without innovation, however: Iktinos repeated his famous strategy with the pi-shaped internal colonnade, and he found another original way to introduce sunlight behind the colonnade by opening a doorway in the eastern wall of the naos (Fig. 3).

And Pheidias went on to Olympia to work on his great statue of Zeus. Beside his workshop he built a 1:1 scale model of the naos of the temple in order to assemble the chryselephantine sculpture. In this case too there is evidence that Pheidias experimented with new ideas, including an array of windows to illuminate his sculpture from the side. 
